tributors were the H. W. Wilson Foundation, Incorporated, Olin Mathieson Charitable Trust, and Pitney-Bowes, Incorporated.

The funds were distributed without regard to location or affiliation of the schools. The Grants Committee for $1969 / 70$ is chaired by H. Vail Deale, Beloit College. The committee members are Humphrey G. Bousfield, Brooklyn College; Miss Johnnie E. Givens, Austin Peay State College; Mrs. Virginia Lacy Jones, Atlanta University; Rev. Vincent R. Negherbon, TOR, Saint Francis College; Mrs. Jessie Carney Smith, Fisk University; and Donald E. Vincent, University of New Hampshire. Philip J. McNiff, president of ACRL and Donald Thomas, Executive Secretary of ACRL were members ex officio.

\section{MAGNETIC TAPE CASSETTES}

A project has been proposed to standardize digital magnetic tape cassettes. These cassettes are used as a vehicle for the magnetic tape storage medium in a variety of keyboarddriven data transcription devices, such as those manufactured by Computer Access Systems, Computer Terminal Corporation, Data Action, IBM, Sanders, Sycor, Viatron, and others. In the absence of standardization a cassette designed to be used with the equipment of one manufacturer is not necessarily usable with the equipment of another. American National Standards Institute (formerly USASI, the United States of America Standards Institute) Committee X3-Computers and Information Processing-Standards Planning and Requirements Committee (SPARC) would like to form an ad hoc committee to advise on the appropriateness of this proposed project. The SPARC is particularly anxious to obtain on this ad hoc advisory committee representatives not only of equipment manufacturers but also of users. If you or your library is a user, either present or planned, of computer input equipment employing magnetic tape cassettes and would like to participate in this useful activity, your contribution will be very much appreciated. For more information contact either Charles A. Phillips, Chairman, ANSI X3, c/o BEMA/DPG, 235 East 42nd Street, New York 10017, or David L. Weisbrod, ALA Representative to ANSI X3, Box 1059 Yale Station, New Haven, Connecticut 06520.

ACRL Membership

December 31, 1969

December 31, 1968

December 31, 1967

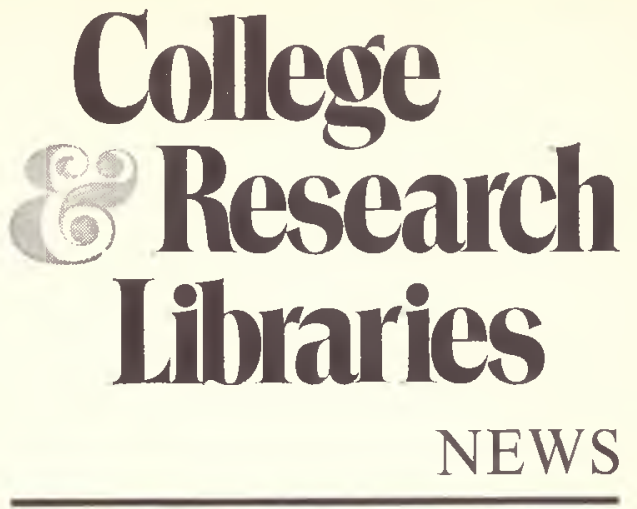

News Editor, Michael Herbison, Casper College, Casper, Wyoming 82601.

Editor, Richard M. Dougherty, University of Colorado Libraries, Boulder, Colorado 80302.

Editorial Board: Richarp DeGennaro, Harvard University; Davm Heron, University of Kansas; EllsWORTH MAson, Hofstra University; Fred Heinartz, Southern Connecticut State College; Wriliam AxFond, Florida Atlantic University; Prter Hiatr, Indiana University.

ACRL Officers, 1969/70: President, Philip J. McNiff; Chairman, College Libraries Section, John E. Scott; Junior College Libraries Section, Ruthe Erickson; Rare Books Section, Robert J. Ádelsperger; Subject Specialists Section, Marcia J. Miller; Agriculture and Biological Sciences Subsection, Howard Rovelstad; Art Subsection, Wolfgang M. Freitag; Educational and Behavioral Science Subsection, Donald Leatherman; Law and Political Science Subsection, Roy M. Mersky; Slavic and East European Subsection, Joseph Placek; University Libraries Section, Roscoe Rouse.

News from the Field, Personnel profiles and notes, classified advertising, official matter of ACRL, and other material of a timely nature is published in the News issues of College $\downarrow$ Research Libraries.

Inclusion of an article or advertisement in CRL does not constitute official endorsement by ACRL or ALA. Production and Advertising and Circulation office: 50 E. Huron St., Chicago, 111. 60611. Change of address and orders for subscriptions should be addressed to College o Research Libraries, for receipt at the above address, at least two months before the publication date of the effective issue.

Subscription to $C R L$ is included in membership dues to $A C R L$ of $\$ 6$ or more; other subscriptions to $C R L$ are $\$ 10$ per year. Neither subscriptions nor memberships include miscellaneous unscheduled supplements, which are available by purchase only. Retroactive subscriptions are not accepted. Single joumal copies are available at $\$ 1.50$ each and News issues at $\$ 1.00$ each from ALA Publishing Department.

Indexed in Current Content, Library Literature, and Science Citation Index. Abstracted in Library Science Abstracts. Book reviews indexed in Book Revieu Index.

College o Research Libraries is the official journal of the Association of College and Research Libraries, a division of the American Library Association; and is published seventeen times per year-bi-monthly as a technical journal with 11 monthly News issues, combining July-August-at 1201-05 Bluff St., Fulton, Mo. 65251 .

Second-class postage paid at Fulton, Mo. 